\title{
Assessing The Extent To Which Internal Procurement Control Systems Are Effective In Safeguarding Inventories: A Case Of Rift Valley Institute Science Technology.
}

\author{
Stephen kipyegon cheruiyot ${ }^{*}$, Dr.Nyangau Andrew ${ }^{1}$, Dr. S. Kiprop ${ }^{2}$, B Koima ${ }^{3}$, \\ Shadrack Koech ${ }^{4}$, Lydia Langat ${ }^{5}$ \\ ${ }^{1}$ Department of Business Studies, Kabarak University, private Bag 2017, Nakuru, Kenya \\ ${ }^{2}$ Department of Business Studies, Kabarak University, private Bag 2017, Nakuru, Kenya \\ ${ }^{3}$ Department of Economics, Egerton University, P.O. Box 536, 20115 Egerton, Kenya \\ ${ }^{4}$ Department of Business, Egerton University, P.O. Box 536, 20115 Egerton, Kenya
}

\begin{abstract}
Internal control systems play a very critical role in the attainment of organizations goals and objectives. Introduction and implementation of such internal controls in all areas of an organization may only be beneficial if it attains the required level of performance or effectiveness. Inventories still remain the biggest cost element in most organizations and especially in learning institutions where they influence the success of their programs. This study sought to assess the extent to which the internal procurement control processes are effective in safeguarding inventories at Rift Valley Institute of Science and Technology (RVIST). A total of 351 employees from all the nine departments in the institute who are involved in the procurement, storage, distribution and usage of inventory were taken for the study's target population. The sample size of 187 employees was selected using stratified sampling method as study's respondents. Structured questionnaires were used as tools for collecting data and were distributed to the respondents with the approval of the relevant authorities. All questionnaires were administered personally by the researcher and the respondents were given one week to fill them. Spearman rank order correlation and regression analysis were used to establish the relationship between internal procurement control systems and the effectiveness in safeguarding inventories. From the findings, internal procurement controls were effective in safeguarding inventories at the institute. The study recommends for due consideration of internal procurement control systems as an integral part of safeguarding and securing inventories
\end{abstract}

Key Words: Internal Control Systems and Safeguarding Inventory

\section{Background of the Study}

According to the University of California (2012), internal controls are defined as a process or systems designed to provide reasonable assurance required to achieve objectives which include effectiveness and efficiency of operations, reliability of financial reporting and compliance with applicable laws and regulations. The Institute of Internal Auditors (2011) looks at internal controls as "any action taken by management, the board, and other parties to enhance risk management and increase the likelihood that established objectives and goals will be achieved". Although the concept of internal control is said to trace its history back to the beginning of the 20th century when audit on financial statements came into being, it has consistently evolved to what it is presently due to continuous change in the business environment (Heier et al (2005). The expansion of the world economy and the scale of enterprises growth after the turn of the century brought about major challenged in management leading to adoption of control systems that encompassed the entire enterprise. During this period "detailed audit" was undertaken on all the target items as an audit of financial statements, but a rapid growth in corporate scale made it virtually impossible to continue the practice.

Rift Valley Institute of Science and Technology (RVIST) was established in 1979 as an institution to advance education and development in the region. It has grown significantly over the last decade to be one of the key institutions within Rift Valley. Its expansion has seen the number of programs increased significantly and by the end of 2012 it has a total workforce of 351 of whom 203 are academic staff and 148 non-teaching staff. The employees estimated to be directly or indirectly involved in procurement, storage and distribution of inventories are 351. 
To enhance the quality of its service delivery and to enhance management of its resources, the institution, initiated a process based management system and constituted an ISO team which developed systems to control operations (Strategic planning committee report, (2009). The institute since June 2010 has been in the process of implementing quality management systems based on International Standards Organization (ISO) 9001:2008 which was expected to be audited for certification on January.

\subsection{Statement of the Problem}

Internal control systems are a fundamental requirement that every organization must incorporate into its management structures. However it is how well they are designed and implemented that will determine their effectiveness in the attainment of goals. Inventory is a significant constituent of the total cost of production of any enterprise and hence calls for effective management and control in order to avoid losses. Given that inventory is a major cost element, it is as key subject of most internal control systems. The institute having misappropriated funds in 2008-2009 financial years alone, most of which were attributed to poor procurement procedure and theft puts into focus the need for immediate interventions (Audit report, 2009). Failure to follow requirements of internal controls as envisaged in implementation of ISO 9001:2008 quality management system (QMS) has since 2010 continuously exposed the institute to higher levels of risk across the entire stock procurement and distribution systems (Annual General Meeting Report, Minute 3/04/2009). Clarity with regard to how internal control systems secure inventory is still unknown and if it is left to continue, it is likely to lead to higher levels of uncertainty, losses and lack of better inventory management systems being developed and implemented. This study therefore sought to establish the effectiveness of internal control systems on inventory control at RVIST.

\subsubsection{Specific Objectives of the Study}

The broad objective of the study in to assess the extent to which internal procurement control systems are effective in safeguarding inventories: A case of Rift Valley Institute Science Technology.

The specific objectives were:

i) To identify the company's procurement process

ii) To establish the authorization process for the large business purchases

iii) To determine how the purchase order process is completed and paid for

\section{Research Hypotheses}

$\mathbf{H O}_{1}$ : Internal procurement control systems have no significant effect in safeguarding inventories at RVIST

\subsection{Significance of the Study}

The study would be of benefit to RVIST as it would provide an analysis of the level to which their efforts in improving their procurement systems had been implemented from its current position. All stakeholders would seek to use the results of this study in coming up with policies that would enable further improvement of their internal inventory control systems. The findings of this study would also create awareness to the ISO 9001:2008 implementation team as it would highlight their performance in the implementation process as well as provide a valuable input into their continual improvement process. Generally, researchers would find the study useful as it gives highlights on areas for further research and also contribute to new knowledge.

\subsection{Scope of the Study}

The study confined itself to Rift Valley Institute of Technology as a case for the study and was limited to internal processes that are core to the procurement, storage and internal distribution of stock items within the institution. The study was carried out between the months of April and May 2013.

\subsection{Limitations and Delimitation of the Study}

The study findings were limited to RVIST and the findings would not be generalized to cover other institutions of higher learning or of similar standings due to the uniqueness of the ISO 9001:2008 implementation strategies that varies from one entity to the other. Not all respondents involved in the procurement and distribution would be free or available for an intensive data collection process. The researcher intentionally used questionnaires designed to allow the respondents fill at their own time within the data collection period. Some of the respondents misrepresented the research process to be a performance evaluation and the researcher was available himself for clarification. During data collection, the researcher accompanied every questionnaire with an official letter to clarify on the objectives of the research as well giving an assurance of it being for academic purposes only. 


\subsection{Theoretical Literature Review}

\section{Literature Review}

According to the Institute of Internal Auditors (2011) internal controls are defined as processes designed to provide reasonable assurance regarding the achievement of objectives. It is also defined as "any action taken by management, the board, and other parties to enhance risk management and increase the likelihood that established objectives and goals will be achieved".

The internal control concept like other modern management frameworks emerged from classical theories that provide a foundation for modern thinking. This study relied on two key theories: systems theory and management control theory, that have found wide recognition in creating deeper understanding of how formal organizations operate.

\subsubsection{The systems Theory}

Systems theory is an interdisciplinary field which studies systems as a whole. Systems theory was founded by Ludwig von Bertalanffy, William Ross Ashby and others between the 1940s and the 1970s on principles from physics, biology and engineering and later was extended into other fields including organizational theory, management, psychotherapy and economics among others (Weinberg, 1975).

By systems, Bertalanffy means 'complexes of elements standing in interaction. The closed system is called closed if it neither takes in nor emits matter (only energy exchange is possible and taken into account). The system is called open if there is a continual input and output of both energy and matter in it. Also, Anthony (1964) added that all systems except the smallest have subsystems and all but the largest have supra systems, which are their environment. Each system or subsystem conceptualized as having a boundary. The boundary of a system is the component that separates the system from its environment and filters the inputs to and the output from the system.

An organization is synonymous with interrelated units or sub systems that must work together to achieve its goal and deliver on mandate. The systems perspective holds that to fully comprehend the function of the entire system, the interrelationships among different components or individual units have to be understood. The internal control system covers all relevant areas of an entity and help in creating a properly organized and controlled unit. Internal control is all-inclusive activity in all areas of organizations operations. However, the most important thing is that internal control should also take into account the objectives and goals of the tasks in order to make as effective as possible Vaclovas \& Giriūnas, (2012). Synonymously, Controlling and safeguarding inventories is considered an organizational wide activity that requires every unit, department or section to participate. Each department or unit will have a unique set of responsibilities and tasks that may be viewed as independent while collectively contributing towards the overall inventory management goal.

The systems theory has over time found extended application in management activities across all sectors. Systems theory has been applied to a wide variety of organizational and management issues including innovation (Shen et al 2009), information systems change (Lytinen and Newman, 2008) and supply chain management (Helou and Caddy, 2006). With the applications of the systems theory is a supply chain context (Helou and Caddy, 2006) found out that it leads to a better understanding of the dynamics within supply chains and how they evolve over time significantly influencing its performance. Recently researchers have suggested that business in general benefits from leveraging a systems perspective in all its activities through the adoption of the systems approach (Atwater et al, 2008; Linden et al, 2007).

\section{Procurement Control Systems}

The first step of an internal inventory control checklist is a review of the company's procurement process. The checklist should include a review of the authorization process for large business purchases, how the purchase order process is completed and how the invoices are paid when the goods are received by the company. The checklist is used to verify that no fraud or collusion is going on that allows employees to purchase personal items with company funds. Additionally, all inventory items purchased should be for legitimate business purposes (Collins, 2012).

\subsection{Research Design}

\section{Research Methodology}

To achieve the objectives of the study, a descriptive research design was conducted in order to enable the researcher to collect data on the effectiveness of internal control systems used by RVIST by use of a structured questionnaire. The researcher administered questionnaires to 187 employees who filled in one week. With descriptive statistics, the researcher presented facts concerning the nature and status of the situation, as they existed at the time of the study and described present conditions, events or systems based on the impressions or reactions of the respondents of the research (Creswell, 1994). 
Descriptive research design allows for systematic description of facts and characteristics of the given population or sample of the population or area of interest factually and accurately (Kothari, 2004). The researcher opted to use this kind of research design considering the desire of the researcher to obtain first hand data from the respondents so as to formulate rational and sound conclusions and recommendations for the study.

\subsection{Study Area}

The study was carried at Rift Valley Institute of Science and Technology main campus situated approximately $10 \mathrm{Km}$ from Nakuru town. The institution currently has a total population of approximately 351 of which 203 are academic staff and 148 non-teaching staff. The target population estimated to have the desired characteristics for the study was 351 . These were the employees who directly participate in stock procurement control, storage and distribution process as well usage of materials.

\subsection{Target Population}

The study collected data from all nine departments and sections of the institute. This was in consideration that the procurement process starts with the consumer of the products or services to be procured and ends with the same once the ordered items are supplied hence all the departments are subject to internal control systems that are in place. From all the nine departments and sections, only 351 staff members who were directly involved in the supply chain were considered to form the target population for the study who were then distributed as indicated in Table 3.1.

Table 3.1 Target Population

\begin{tabular}{lc}
\hline \multicolumn{1}{c}{ Department } & Number of employees \\
\hline Administration & 29 \\
Tender committee & 28 \\
& \\
Procurement & 41 \\
& 37 \\
Accounts & 38 \\
Stores & 37 \\
Catering & 53 \\
HODs (academic departments) & 42 \\
Security & 46 \\
House keeping & $\mathbf{3 5 1}$ \\
\hline Total &
\end{tabular}

Source: HRM RVIST (2013)

\subsection{Sampling Design and Sample Size}

The accuracy of research findings generalization to the wider population is highly influenced by the selection of the right sample size. According to Mugenda and Mugenda (2003), a sample size of $10 \%-20 \%$ of the population is considered representative, however, where time and resources allow, the researcher should take a bigger/larger sample for better inferences. For this study, the sample size was determined by the use of the following formula developed by Cochran (1963)

$$
\begin{aligned}
& \text { N } \\
& \mathrm{n}=1+N\left(e^{2}\right) \\
& \text { Where; } \quad \mathrm{n}=\text { the desired Sample size } \\
& \mathrm{N}=\text { the population } \\
& \mathrm{e} \quad= \pm 0.05 \text {, is the level of precision }
\end{aligned}
$$

Therefore the sample size was:

$$
\begin{aligned}
\mathrm{n}= & \frac{351}{1+351\left(0.05^{2}\right)} \\
& =\quad 187 \text { respondents }
\end{aligned}
$$

A total of 187 employees were selected to participate in the study. With the target population already grouped into different strata, stratified sampling techniques were found to be the most appropriate. Stratified sampling was used to select the employees who participated in the study. In each stratum or department simple 
random sampling was used to select respondents. Allocation of each stratum was done through proportional stratified random sampling given in the following formula below:

$$
n_{i}=\underline{n} \quad * \mathrm{~N}_{i} \underline{187} \times 29=15
$$

(For Administration as an example)

Where, $\mathrm{n}_{\mathrm{i}}=$ Number of members in the sample from strata $\mathrm{i}$ for $\mathrm{i}=1,2,3,4 \ldots . .9$

$\mathrm{N}_{\mathrm{i}}=$ Number of members in the population from strata $\mathrm{i}$ for $\mathrm{i}=1,2,3,4 \ldots \ldots 9$

$\mathrm{N}=$ Number of members in the entire population

$n=$ Sample size. In administration for example, stratum size $=29 / 351(187)=15$. Their distributions were as provided in Table 3.2 .

Table 3.2: Selection of Sample Size

\begin{tabular}{|c|c|c|}
\hline Department/strata & Number of employees & Sample size \\
\hline Administration & 29 & 15 \\
\hline Tender committee & 28 & 15 \\
\hline Procurement & 41 & 22 \\
\hline Accounts & 37 & 20 \\
\hline Stores & 38 & 20 \\
\hline Catering & 37 & 20 \\
\hline HODs & 53 & 28 \\
\hline Security & 42 & 22 \\
\hline House keeping & 46 & 25 \\
\hline Total & 351 & 187 \\
\hline
\end{tabular}

The nine departments represented the different strata and the choice of stratified sampling allowed the sampling process to incorporate proportionate representation of each group in the final sample hence eliminating any group misrepresentation that would arise in the sampling process.

\subsection{Data Collection Instruments}

A structured questionnaire was developed taking into consideration the four specific inventory processes in the procurement cycle and in line with the study's objectives.

After taking into consideration that the data would be collected during normal working hours, the questionnaires were given to the selected respondents and a period of one week was available for them to fill before collecting. This was expected to give them adequate time to respond to the questions and hence minimize chances of incomplete questionnaires. The researcher personally distributed the questionnaires and explained the purpose of the data collection process so as to reduce on chances of wrong perception being attached to the process. Heads of sections and departments were consulted to assist in encouraging the respondents to participate.

\subsection{Validity and Reliability of Research Instruments}

Cronbach's alpha reliability coefficient was calculated to estimate the reliability of the data. The results of the correlated sets gave the researcher positive correlation coefficient of 0.7 which showed that the instrument was reliable. These are within the threshold of 0.7 which is considered good (Sekaran, 2000).

\subsection{Data Analysis and Presentation}

Once all questionnaires were collected, the data were cleaned and coded into Statistical Package for Social Sciences (SPSS) for analysis. Using descriptive statistics inform of frequencies and percentages, the researcher established the general characteristics of the respondents and their responses on general research items in the questionnaires by use of a Likert scale or summated scale. Most of these analyses were presented in form of tables and charts. Inferential analysis was done with the aid of SPSS (Statistical Package for Social Scientist Version 20) where Pearson's correlation coefficient was used to test the relationship between the procurement, stores, distribution and organizational internal control policies against the effectiveness achieved. Further regression analysis was used to assess the extent to which each of the specific internal control processes had contributed to the overall effectiveness achieved. Both of the above analysis was used as the basis of rejecting or accepting the research hypotheses.

Since the variables involved were more than two, multiple regression analysis was done to determine the relationship, where: 
The equation was in the form: $Y=a_{0}+a_{1} x_{1}+a_{2} x_{2}+\ldots .+a_{n} x_{n}+\dot{\varepsilon}$

Where $Y=a_{i}$ are coefficients to be estimated, $Y$ is the dependent variable and $x_{i}$ are the independent variables and e the error term.

$\left(\mathrm{x}_{1}\right)=$ internal procurement controls

$\left(\mathrm{x}_{2}\right)=$ internal stores controls

$\left(\mathrm{x}_{3}\right)=$ internal stores distribution controls

$\left(\mathrm{x}_{4}\right)=$ internal management controls

$\mathrm{e}=$ error term normally distributed with zero mean and variance

To enhance understandability of the results, tables, charts and graphs were used in presentation each accompanied by a descriptive narrative

\subsection{Ethical Considerations}

Permission to carry out the study was sought from Kabarak University, and from the respondents who participated in the study. The nature and the rationale for the study were explained to the respondents by the researcher. The researcher would respect the individuals' rights and also safeguard their personal integrity. In the course of the research, the respondents were assured of confidentiality.

\subsection{Introduction}

\section{Data Analysis, Presentation And Interpretation}

This chapter presents the analysis of data collected in the field through the use of questionnaires that were administered to employees of RVIST. A total of 187 questionnaires were issued and 171 were collected back of which 3 were rejected for being incomplete for analysis leaving 168 questionnaires for analysis. This represents $89.8 \%$ response rate adequate for any inferential analysis and meaningful conclusions in research.

\subsection{Respondents Characteristics}

\subsubsection{Age of the respondents}

The age distribution of the respondents were examined and the outcome was as presented in Table

\subsection{1}

From the analysis it was evident that a majority making up $39.9 \%$ of the respondents were aged between $31-40$ years followed by those who were aged between $20-30$ years represented by $21.4 \%$. Those who were aged below 20 years accounted for $16.1 \%$ while those between $41-50$ years and above 50 years made up $13.1 \%$ and $9.5 \%$ of the respondents respectively.

\subsubsection{Gender of the Respondents}

Each of the respondents was requested to indicate their gender as one of the key attributes of mapping out respondent's characteristics. Their responses were as provided in Table 4.2.2:

From the analysis majority of the respondents (66.1\%), were male while $33.9 \%$ were female. This shows that male respondents were more than female.

\subsubsection{Respondents Work experience}

To establish the respondents experience with the internal control systems in use at RVIST they were requested to indicate the number of years they have worked for the institution and their response were as presented in Figure 4.2.3:

The results indicate that majority of the respondents (44\%) had experience of between $1-4$ years, while $40 \%$ have experience of between $5-9$ years. $11 \%$ of the respondents indicated that they had experience of more than 10 years while $4 \%$ had experience of less than 1 year. This gave the findings of the research more confidence since a good proportion of the respondents had a good exposure on the internal control systems used by the institution. 


\subsubsection{Respondent's Departmental distribution}

The distribution of the respondents across the representative departments included in the study were as indicated in Table 4.2.4

Response from the administration department accounted for $8 \%$ of the total respondents and $93 \%$ of what was expected from the department was received. The tender committee represented $7 \%$ of the entire sample group with $80 \%$ response rate attained in the department. The response from the procurement department represented $12 \%$ of the total response received, internally attaining a $91 \%$ response rate. Accounts, stores catering and security equally contributed $11 \%$ in the total response received while each returning $90 \%$, $95 \%, 90 \%$ and $86 \%$ response internally respectively. The head of departments in academic departments represented $15 \%$ of the response rate while $95 \%$ of what was expected was received. Housekeeping accounted for $13 \%$ of the total respondents while $88 \%$ of the expected respondents returned filled questionnaires. All the departments therefore were represented proportionately in the analysis with adequate response rate achieved from all the departments within the institute.

\subsubsection{Overall responsibility for determining departmental procurement needs}

The overall responsibility for determining departmental procurement need and hence the initiation of the process were indicated by the respondents as presented in Table 4.2.5

It was established that majority $(43 \%)$ of the departments were vesting the responsibility of determining its procurement need on the Head of department. This was followed by sections head as was indicated by $22 \%$ of the respondents. Sixteen percent $(16 \%)$ of the respondents noted that it was the user while $14 \%$ and $5 \%$ indicated that it was their foreman and storekeeper respectively.

\subsubsection{Responsibility for communicating requisitions}

Those with the specific responsibility of preparing and communicating departmental needs through the relevant procurement channels were as indicated in Table 4.2.6

Majority (59\%) of the departments were using the Head of department as their key communicator followed by sections head as was indicated by $22 \%$ of the respondents. Ten percent $(10 \%)$ of the respondents noted that it was their store keeper while $7 \%$ and $2 \%$ indicated that it was their foreman and user respectively. This indicated that the heads of the sections or departments were given the responsibility of facilitating the procurement processes on behalf of their departments or units.

\subsubsection{Inventory control procedures used}

The approaches used in safeguarding inventory internally were as indicated in Table 4.2.7

Seventy three percent $(73 \%)$ of the respondents indicated that they were carrying out inspections on any products that were either coming in or being issued to ascertain their quantities and nature. Record keeping was used by $92 \%$ of the respondents while $83 \%$ made sure that there was proper storage of their inventory items. Secure custody of store keys was noted by $73 \%$ of the respondents while $64 \%$ noted that there were proper procedure put in place to allow for safe keeping and securing of inventories. Segregation of duties was noted by $88 \%$ while $7 \%$ noted other procedures including continuous stock checks and periodic audits. This was an indication that the different approaches were being used in ensuring that inventories were safe and secure, notably use of records and assigning duties being the most widely used.

\section{Internal procurement Inventory Control System}

Respondents were asked to respond to a number of prepositions used as measures of the state of the institute's procurement control systems and their feedback were as indicated in Table 4.4.1

Forty Six $(46 \%)$ percent of the respondents strongly agreed that their department was relying on the purchasing unit to coordinate the procurement of goods and services required. While $25 \%, 17 \%$ were undecided and disagreed respectively and $12 \%$ agreed.

Half (51\%) strongly agreed that their department was fully responsible for determining the goods and services required while $32 \%$ agreed and $17 \%$ were however undecided. Forty seven percent $(47 \%)$ of the respondents strongly agreed that there was existence of internal systems for monitoring period's inventory needs while $32 \%, 16 \%, 2 \%$ and $3 \%$ agreed , were undecided, disagreed and strongly disagreed respectively. The notion that all purchases within the department were fully centralized and controlled by assigned individuals was strongly supported by $55 \%$ of the respondents, $16 \%$ agreed, $25 \%$ were undecided and $4 \%$ disagreed.

The presence of clear and adequate written instructions on how to request for products or services through the department was strongly acknowledged by $32 \%$ of the respondents while $36 \%$ were just in agreement. $25 \%$ were undecided while $7 \%$ disagreed. Presence of adequate supervision and control against excessive and unnecessary procurement of goods and services received a strong agreement from $46 \%$ of the 
respondents while $29 \%$ were in agreement. Twenty one (21\%) percent were undecided while $4 \%$ disagreed. More than half (52\%) of the respondents strongly agreed that all the necessary documentation must be availed before a requisition being processed while $24 \%$ responded in agreement, $19 \%$ were undecided while $5 \%$ were in disagreement. Existence of clarity in individual responsibilities and limits in the procurement process received a strong agreement from $46 \%$ of the respondents while $31 \%$ and $23 \%$ were in agreement and undecided respectively. Forty one percent (41\%) of the respondents were in strong agreement that all product and services procured were used for the intended purpose. The same proportion was also in agreement while $15 \%$ and $4 \%$ were undecided and disagreed respectively. All the above response areas returned a Chi square values that were significant $(\mathrm{P}$ values $<0.05$ ). It was clear from the above findings that most of the respondents were in agreement that the procurement internal control systems were contributing to inventory safety and security.

\section{Hypothesis Testing}

To test the significance of the four components of the internal inventory control system in explaining the overall effectiveness achieved in safeguarding inventory. The $\mathrm{p}$-level represents the probability of error that is involved in accepting the observed result as valid, that is, as a representative of the population (MacColl, 2004). The results were as presented in Table 4.10.1

\section{$\mathrm{HO}_{1}$ : Procurement Internal control systems have no significant effect in safeguarding inventories at RVIST}

From the Table 4.10.1, the results reveal that there is a strong positive relationship between procurement control systems and safeguarding of inventories $(\mathrm{r}=0.719, \mathrm{p}<0.05)$. Hypothesis states that procurement internal control systems have no significance in safeguarding inventories. The researcher therefore rejected the hypothesis and concludes that there is sufficient evidence at $5 \%$ level of significance that procurement internal control systems have a significant effect in safeguarding inventories at RVIST.

The results in table 4.11.1 shows that there is a positive relationship between internal control systems and safeguarding of inventories $(R=0.825)$. Coefficient of determination $\left(R^{2}\right)$ is 0.681 . This shows that $68.1 \%$ variation effectiveness of safeguarding is explained by internal control systems.

\section{Discussion, Conclusion And Recommendation}

The role of the procurement stage in influencing the effectiveness of the inventory control was notably evident in the institute. Relying on the purchasing unit to coordinate the procurement of goods and services as an expert department and the presence of clear and adequate written procedures on how to request for products or services through the department was strongly evident. Existence of adequate documentation process accompanied by clarity in individual responsibilities and limits in the procurement process to ensure that unnecessary procurements are minimized was also evident. This was in concurrence with the finding of Fagbulo (2012) and Jongh, (2010) in their studies on effects and utilization of internal controls in hospitality and fast food SMEs. The rejection of the null hypothesis and a conclusion that internal procurement was effective in safeguarding and securing of inventory, was therefore a clear confirmation that inclusion of procurement as a component of internal inventory control systems is necessary if the overall objectives of the system are to be achieved.

The measures put in place at the procurement stage starting with the need of determination of requirements to the inspection of the supplies were effective in safeguarding and securing the inventories. Such measures have contributed significantly to the attainment of the overall levels of effectiveness of the institutes internal control system. At the storage level, measures directed towards reducing losses, theft deterioration of quality and enhanced record keeping have significantly enhanced the effectiveness of the inventory control systems at the institute. Similarly, distribution of stocks from the stores to the user departments was also performing well in relation to safety and security against losses and misuse despite being the least contributor to the overall effectiveness achieved.

In light of the above findings, the researcher recommends the following to be taken into consideration. First, the favourable results indicating high levels of effectiveness having been achieved in the safeguarding and securing inventories calls for the completion of the ISO: 9000 quality management systems implementation. The findings of this study confirm the results and benefits attained so far in its implementation and giving a justification for its full implementation. Moreover the benefits accruing from implementation of internal control system would accrue enormous benefits to the entire organization. $\underline{\mathrm{s}}$ 


\section{References}

[1]. Anthony R. N., and Govindarajan V. (1998). Management control systems (9th ed.). Burr Ridge, IL: Irwin McGraw-Hill

[2]. Atwater, J. B., Kannan, V. R., and Stephens, A. A. (2008). Cultivating Systemic Thinking in the Next Generation of Business Leaders. Academy of Management Learning \& Education, 7(1), 9-25.

[3]. Collins, J. (2012). How to Determine Inventory Control.www.eHow.com. Retrieved on 12, November, 2012

[4]. Cochran, W. G. 1963. Sampling Techniques, 2nd Ed. New York: John Wiley and sons, Inc.

[5]. Creswell, J. W. (1994). Research designs: Qualitative and quantitative approaches. Tata McGraw hill, New Delhi

[6]. Heirer, I. R, Dogan, M. T. \& Sayers , D. L.( 2005) “ A centuary of debate for internal controls” Accountin History, Vol.(3) pg 3970

[7]. Institute of Internal Auditors (2011).Standards and Guidelines, Governance, Risk Management and Controls. The Institute of Internal Auditors

[8]. Kothari, C.R. (2004). Research Methodology: Methods and Techniques, $2^{\text {nd }}$ Edition. New Delhi: New Age International Press.

[9]. Linden, L. P., Kuhn, J. L., Parrish, S. M., Richardson, Adansm L. A., Elgarah, W., Courtney, J. F. (2007). Churchman's Inquiring Systems: Kernel Theories for Knowledge Management. Communications of the Association for Information Systems, $20,836-871$.

[10]. Lyytinen, K., and Newman, M. (2008). Explaining information systems change: a punctuated socio-technical change model. European Journal of Information Systems, 17(6), 589-613.

[11]. Mugenda O \& Mugenda A. (2003). Research Methods: Quantitative and Qualitative approaches, Nairobi: Acts Press.

[12]. Sekaran, U.2000.Research methods for business. A skilled building approach, $\left(3^{\text {rd }}\right.$ ed.)New York: Wiley

[13]. Shen, H. Wang, L. Xu, Q., Li, Y. and Liu, X. (2009). Toward a Framework of Innovation Management in Logistics Firms: A Systems Perspective. Systems Research and Behavioral Science, 26, 297-309.

[14]. University of California (2012).Understanding Internal Controls. http://www.ucop.edu. . Retrieved 12, November, 2012.

[15]. Vaclovas, L. and Giriūna. L. (2012). The Concept of Internal control system: Theoretical aspect. Ekonomika vol. 91(2).

[16]. Weinberg, G. M. (1975) An Introduction to General Systems Thinking (1975 ed., Wiley-Inter-science) (2001 ed. Dorset House).

Table 4.2.1 Age distribution of the respondents

\begin{tabular}{|l|c|c|}
\hline \multicolumn{1}{|c|}{ Age Bracket } & Valid count & Percentage \\
\hline Below 20 Years & 27 & $16.1 \%$ \\
\hline Between 20-30 Years & 36 & $21.4 \%$ \\
\hline Between 31-40Years & 67 & $39.9 \%$ \\
\hline Between 41-50Years & 22 & $13.1 \%$ \\
\hline Over 50 Years & 16 & $9.5 \%$ \\
\hline
\end{tabular}

Source: Research data, 2014

Table 4.2.2 Gender distribution

\begin{tabular}{|l|c|c|}
\hline Gender & Valid count & Percentage \\
\hline Male & 111 & $66.1 \%$ \\
\hline Female & 57 & $33.9 \%$ \\
\hline Total & 168 & $100 \%$ \\
\hline
\end{tabular}

Source: Research Data, 2014

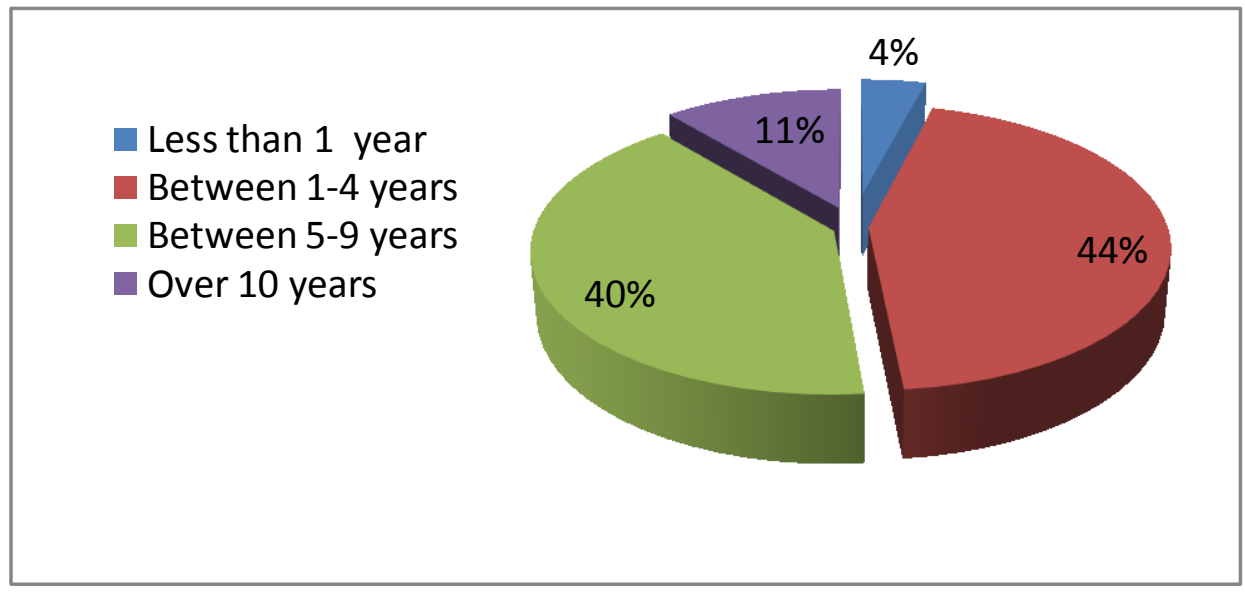

Figure 4.2.3: Years of Experience

Source: Research Data, 2014 
Table 4.2.4 Response per department

\begin{tabular}{|l|c|c|c|}
\hline Department & No of Respondents & $\begin{array}{c}\text { Proportion } \\
\text { In the total response }\end{array}$ & $\begin{array}{c}\text { Departmental } \\
\text { Response Rate }\end{array}$ \\
\hline Administration & 14 & $8 \%$ & $93 \%$ \\
\hline Tender committee & 12 & $7 \%$ & $80 \%$ \\
\hline Procurement & 20 & $12 \%$ & $91 \%$ \\
\hline Accounts & 18 & $11 \%$ & $90 \%$ \\
\hline Stores & 19 & $11 \%$ & $95 \%$ \\
\hline Catering & 18 & $11 \%$ & $90 \%$ \\
\hline HOD(academic departments) & 26 & $15 \%$ & $93 \%$ \\
\hline Security & 19 & $11 \%$ & $86 \%$ \\
\hline House Keeping & 22 & $13 \%$ & $88 \%$ \\
\hline
\end{tabular}

Source: Research Data, 2014

Table 4.2.5 Responsibility for determining procurement needs

\begin{tabular}{|l|c|c|}
\hline \multicolumn{1}{|c|}{ Individual/office responsible } & Frequency & Valid percentage (\%) \\
\hline HOD & 72 & 43 \\
\hline HOS & 37 & 22 \\
\hline User & 27 & 16 \\
\hline Store keeper & 8 & 5 \\
\hline Foreman & 24 & 14 \\
\hline
\end{tabular}

Source: Research Data, 2014

Table 4.2.6 Communication Responsibility

\begin{tabular}{|l|c|c|}
\hline \multicolumn{1}{|c|}{ Individual responsible } & Frequency & Valid percentage (\%) \\
\hline HOD & 99 & 59 \\
\hline HOS & 37 & 22 \\
\hline User & 4 & 10 \\
\hline Store keeper & 16 & 7 \\
\hline Foreman & 12 & 2 \\
\hline
\end{tabular}

Source: Research Data, 2014

Table4.2.7. Internal control methods used

\begin{tabular}{|l|c|c|}
\hline \multicolumn{1}{|c|}{ Procedure/Method used } & Frequency & Valid percentage (\%) \\
\hline Inspection on entry \& exit & 123 & 92 \\
\hline Record keeping & 154 & 83 \\
\hline Proper storage & 139 & 73 \\
\hline Secure custody of storage keys & 122 & 64 \\
\hline Proper Handling procedures & 108 & 88 \\
\hline Segregation of duties & 148 & 7 \\
\hline Others & 12 & \\
\hline
\end{tabular}

Source: Research Data, 2014

Table 4.4.1 Procurement Control Systems

\begin{tabular}{|c|c|c|c|c|c|c|}
\hline Response statement & SA & $\mathbf{A}$ & $\mathbf{U}$ & D & SD & $\begin{array}{c}\chi^{2} \\
\text { (P-Value) }\end{array}$ \\
\hline $\begin{array}{l}\text { Our department rely on the Purchasing Department to } \\
\text { coordinateproaurement for goodsandservices }\end{array}$ & $\begin{array}{c}78 \\
(46 \%)\end{array}$ & $\begin{array}{c}42 \\
(25 \%)\end{array}$ & $\begin{array}{c}28 \\
(17 \%)\end{array}$ & $\begin{array}{c}20 \\
(12 \%)\end{array}$ & $\begin{array}{c}0 \\
(0.0 \%)\end{array}$ & $\begin{array}{l}34.905 \\
(0.000)\end{array}$ \\
\hline $\begin{array}{l}\text { Our department is fully responsible for determining the } \\
\text { goodor servicesweneed }\end{array}$ & $\begin{array}{c}86 \\
(51 \%)\end{array}$ & $\begin{array}{c}54 \\
(32 \%)\end{array}$ & $\begin{array}{c}28 \\
(17 \%)\end{array}$ & $\begin{array}{c}0 \\
(0.0 \%)\end{array}$ & $\begin{array}{c}0 \\
(0.0 \%)\end{array}$ & $\begin{array}{l}139.500 \\
(0.000)\end{array}$ \\
\hline $\begin{array}{l}\text { We have our own intermal system to monitor what we } \\
\text { needineveryperiod }\end{array}$ & $\begin{array}{c}79 \\
(47 \%)\end{array}$ & $\begin{array}{c}54 \\
(32 \%)\end{array}$ & $\begin{array}{c}27 \\
(16 \%)\end{array}$ & $\begin{array}{c}3 \\
(2 \%)\end{array}$ & $\begin{array}{c}5 \\
(3 \%)\end{array}$ & $\begin{array}{l}85.988 \\
(0.000)\end{array}$ \\
\hline $\begin{array}{l}\text { All purchases within our department are full centralized and } \\
\text { controlledbyassignedindividuals }\end{array}$ & $\begin{array}{c}93 \\
(55 \%) \\
\end{array}$ & $\begin{array}{c}26 \\
(16 \%) \\
\end{array}$ & $\begin{array}{c}42 \\
(25 \%) \\
\end{array}$ & $\begin{array}{c}7 \\
(4 \%) \\
\end{array}$ & $\begin{array}{c}0 \\
(0.0 \%) \\
\end{array}$ & $\begin{array}{l}73.476 \\
(0.000)\end{array}$ \\
\hline $\begin{array}{l}\text { There are clear and adequate witten instructions on how to } \\
\text { request for productsservices required through the } \\
\text { depertment }\end{array}$ & $\begin{array}{c}54 \\
(32 \%)\end{array}$ & $\begin{array}{c}60 \\
(36 \%)\end{array}$ & $\begin{array}{c}42 \\
(25 \%)\end{array}$ & $\begin{array}{c}12 \\
(7 \%)\end{array}$ & $\begin{array}{c}0 \\
(0.0 \%)\end{array}$ & $\begin{array}{l}146.940 \\
(0.000)\end{array}$ \\
\hline
\end{tabular}




\begin{tabular}{|l|c|c|c|c|c|c|}
\hline $\begin{array}{l}\text { There is adequate supervision and control against } \\
\text { proaurementofexcessandunnecessary goodsservices? }\end{array}$ & $\begin{array}{c}77 \\
(46 \%)\end{array}$ & $\begin{array}{c}49 \\
(29 \%)\end{array}$ & $\begin{array}{c}36 \\
(21 \%)\end{array}$ & $\begin{array}{c}6 \\
(4 \%)\end{array}$ & $\begin{array}{c}0 \\
(0.0 \%)\end{array}$ & $\begin{array}{c}85.155 \\
(0.000)\end{array}$ \\
\hline $\begin{array}{l}\text { All the required documents are mandatory before a } \\
\text { requisitionisprocessed }\end{array}$ & $\begin{array}{c}88 \\
(52 \%)\end{array}$ & $\begin{array}{c}40 \\
(24 \%)\end{array}$ & $\begin{array}{c}31 \\
(19 \%)\end{array}$ & $\begin{array}{c}9 \\
(5 \%)\end{array}$ & $\begin{array}{c}0 \\
(0.0 \%)\end{array}$ & $\begin{array}{c}137.179 \\
(0.000)\end{array}$ \\
\hline $\begin{array}{l}\text { Everyone is aware of their responsibilities and limits in the } \\
\text { requisitionprocess }\end{array}$ & $\begin{array}{c}78 \\
(46 \%)\end{array}$ & $\begin{array}{c}52 \\
(31 \%)\end{array}$ & $\begin{array}{c}38 \\
(27 \%)\end{array}$ & $\begin{array}{c}0 \\
(0.0 \%)\end{array}$ & $\begin{array}{c}0 \\
(0.0 \%)\end{array}$ & $\begin{array}{c}25.857 \\
(0.000)\end{array}$ \\
\hline $\begin{array}{l}\text { Allrequisitionedproducts/servicesaredirectlyused for } \\
\text { theintendedpumose/need }\end{array}$ & $\begin{array}{c}69 \\
(41 \%)\end{array}$ & $\begin{array}{c}68 \\
(41 \%)\end{array}$ & $\begin{array}{c}25 \\
(15 \%)\end{array}$ & $\begin{array}{c}6 \\
(4 \%)\end{array}$ & $\begin{array}{c}0 \\
(0.0 \%)\end{array}$ & $\begin{array}{c}95.000 \\
(0.000)\end{array}$ \\
\hline
\end{tabular}

\section{Correlations}

\begin{tabular}{|ll|r|r|r|r|r|}
\hline & & $\begin{array}{c}\text { Securing } \\
\text { SafeguardTotal } \\
\text { core }\end{array}$ & $\begin{array}{c}\text { PICS Total } \\
\text { Score }\end{array}$ & $\begin{array}{c}\text { SCS Total } \\
\text { Score }\end{array}$ & $\begin{array}{c}\text { SDCS Total } \\
\text { Score }\end{array}$ & $\begin{array}{c}\text { MCP Total } \\
\text { Score }\end{array}$ \\
\hline securingSafegua & Pearson Correlation & 1 & $.719^{* *}$ & $.608^{* *}$ & $.375^{* *}$ & $.785^{* *}$ \\
rdTotalScore & Sig. (2-tailed) & & .000 & .000 & .000 & .000 \\
& $\mathrm{~N}$ & 168 & 168 & 168 & 168 & 168 \\
PICS & Pearson Correlation & $.719^{* *}$ & 1 & $.497^{* *}$ & $.193^{* *}$ & $.543^{* *}$ \\
& Sig. (2-tailed) & .000 & .000 & .012 & .000 \\
TotalScore & $\mathrm{N}$ & 168 & 168 & .168 & 168 & 168 \\
\hline
\end{tabular}

Table 4.11.1 Regression Model Summary

\begin{tabular}{|c|c|c|c|c|c|c|c|c|c|}
\hline \multicolumn{10}{|c|}{ Model Summary } \\
\hline \multirow[t]{2}{*}{ Model } & \multirow[t]{2}{*}{$\mathrm{R}$} & \multirow[t]{2}{*}{ R Square } & \multirow{2}{*}{$\begin{array}{l}\text { Adjusted R } \\
\text { Square }\end{array}$} & \multirow{2}{*}{$\begin{array}{l}\text { Std. Error } \\
\text { of the } \\
\text { Estimate }\end{array}$} & \multicolumn{5}{|c|}{ Change Statistics } \\
\hline & & & & & $\begin{array}{l}\text { R Square } \\
\text { Change }\end{array}$ & F Change & df1 & df 2 & $\begin{array}{c}\text { Sig. F } \\
\text { Change }\end{array}$ \\
\hline 1 & $.825^{\mathrm{a}}$ & .681 & .679 & 1.226 & .681 & 354.490 & 1 & 166 & .000 \\
\hline
\end{tabular}

Source: Research data (2014) 